\title{
Haiti: The Development of "Seamless" Assistance from Disaster Relief to UNPKOs
}

\section{The Complex Crisis in Haiti}

Haiti occupies the western side of the island of Hispaniola in the Caribbean Sea. The country was initially colonized by Spanish settlers and later came under French control. Although Haiti achieved independence as early as 1804 , it suffered from repeated rebellions and divisions and eventually caused a US military occupation in 1915 that lasted nearly two decades. Even after the US withdrawal in 1934, Haiti was continuously trapped in a vicious circle of military coups and dictatorships, as well as its weak economy.

Following Jean-Bertrand Aristide's controversial inauguration as the democratically elected president in 1991, Haitian domestic politics fell into further confusion in the acute rivalry between the pro- and antiAristide forces. In February 2004, an anti-government uprising forced President Aristide to flee the country. The UNSC authorized the deployment of the US-led Multinational Interim Force (MIF) from the beginning of March (United Nations, 2004), as a short-term military deployment for the rapid recovery of public order. After the recovery of temporary security by the MIF, the United Nations Stabilization Mission in Haiti (MINUSTAH) was established three months later. Even after the deployment of the UN mission, Haiti remained in chaos, not just because of continuing political instability and economic stagnation but also due to a series of severe natural disasters, such as three consecutive great hurricanes in 2008 .

(C) The Author(s) 2022

H. N. Fujishige et al., Japan's Peacekeeping at a Crossroads, Sustainable Development Goals Series, https://doi.org/10.1007/978-3-030-88509-0_7 
Even more seriously, a magnitude 7.0 earthquake rocked Haiti on January 12, 2010, affecting more than three million people, or nearly a third of the entire population (JICA, n.d.). According to the available records, the disaster victims included almost 222,000 dead and more than 300,000 wounded. This struck a fatal blow to the already weak governance system and infrastructure of the country, further harming public order.

In cases of complex crisis, where a large-scale natural disaster occurs during or soon after an armed conflict, the loss of public order can easily become a major issue, making these situations very different from regular emergency disaster relief. The international personnel who arrived in Haiti immediately after the 2010 earthquake were therefore concerned about two concurrent challenges, namely the damage from the natural disaster and serious violent disorder. Following the great earthquake, chaos in the country was further intensified, with ongoing damage to infrastructure, government paralysis, and rioting and plundering of aid by refugees. Consequently, the US military was deployed alongside MINUSTAH and tasked with maintaining public order in the disaster zone.

\section{INTERNATIONAL BACKGROUND}

\subsection{International Support to Haiti}

As seen above, Haiti has been almost perennially in turmoil since its independence in the early nineteenth century. To cope with the anti-Aristide uprising in 2004, the MIF was initially deployed under UNSCR 1529 to establish and maintain public safety and the rule of law. It was obvious, however, that Haiti needed more long-term assistance to rebuild itself, not only to improve the situation for its own population but also to prevent the massive outflux of refugees to the neighboring countries, including the US. As a result, UNSCR 1542 in 2004 was also passed, establishing MINUSTAH. The UNPKO inherited a "robust" mandate from the MIF to secure a safe and stable environment in Haiti, but it was also an integrated mission designed to engage in statebuilding. In other words, MINUSTAH took on the characteristics of "robustness" and "integration" simultaneously. 


\subsection{Post-earthquake Restoration and Reconstruction}

The 2010 earthquake not only damaged local facilities and the population, but also sacrificed approximately $100 \mathrm{UN}$ workers in the collapse of the MINUSTAH Headquarters. International momentum to support Haiti's reconstruction increased soon after the earthquake. A week later, on January 19, UNSCR 1908 was adopted to renew the mandate for MINUSTAH: its maximum strength was increased by 3500 (an additional 2000 military and 1500 police personnel) to stabilize the nation. Accordingly, MINUSTAH's mandate was switched to one of emergency restoration and reconstruction.

Massive amounts of foreign emergency aid poured into Haiti after the earthquake; however, the international society doubted the Haitian government's ability to monitor and distribute that aid (Uesugi, 2018, p. 193). The Haitian Prime Minister Jean-Max Bellerive and the former US President Bill Clinton therefore created the Interim Haiti Reconstruction Committee (IHRC), with both acting as joint chairpersons (Clinton, 2010). Furthermore, the Haiti Relief Fund (HRF) was created by Haiti's Ministry of Finance and the World Bank to manage the huge amounts of reconstruction aid and to disperse these funds to reconstruction companies.

\section{Political Background to Japan's Participation}

\subsection{Haiti as an Earthquake Disaster Zone}

Since Japan itself historically suffered from a number of earthquakes, exemplified by the Great Hanshin-Awaji (Kobe) Earthquake in 1995, both the GoJ and broader society had high incentive to assist Haiti after the earthquake. ${ }^{1}$ The Japanese public had high expectations not only for the dispatch of a civilian assistance team, but also for military deployment. In the Cabinet Office's 2009 survey asking the public to provide a raison d'etre for the SDF, nearly 80 percent of the respondents chose disaster relief as their answer, followed by 70 percent who chose national defense and just over 40 percent who chose IPC (Cabinet Office, 2009).

Bolstered by strong public support for the purpose of disaster relief, the GoJ dispatched two successive medical contingents based under the JDR Act: first a civilian medical team, followed by an SDF medical unit. When the SDF medical unit departed, the Japanese Red Cross Society (JRCS) 
took over medical assistance to Haiti. Following this initial phase of medical support, SDF peacekeepers were deployed to MINUSTAH under the PKO Act. The GoJ's decision on the military contribution to MINUSTAH raised little disagreement, since they were mandated for restoration and reconstruction after the earthquake.

\subsection{The DPJ Administration}

The decline of anti-military opposition in Japan also facilitated the GoJ's rapid decision to deploy the SDF to post-disaster Haiti. The LDP stepped down from power in 2009 and was replaced with the DPJ government, with Yukio Hatoyama as the prime minister. This contributed to further weakening of anti-military resistance both at the Diet and in society. This decline was not only because the DPJ itself took a positive stance toward the UNPKOs, but also because the primary anti-military political force, the SDP, was now a part of the DPJ-led coalition government under Hatoyama's premiership. This made it difficult for the anti-military party to uphold its persistent objections against SDF overseas deployment. Consequently, anti-military opposition from society was much less visible when the SDF deployment to MINUSTAH was decided. The formation of the DPJ government thus shrank domestic opposition to SDF overseas deployment and created a political environment that allowed the fastestever deployment decision to be made.

\subsection{Consideration of the US Ally}

The alliance relationship with the US also reinforced the GoJ's decision regarding the personnel deployment to Haiti. Prior to the 2009 change in government, the DPJ had stated that it would cut off Japan's refueling support in the Indian Ocean, which had provided indirect assistance to the "War on Terror" in Afghanistan (see Chap. 3). The DPJ insisted that the legal basis of refueling support was unclear in terms of UNSCRs and its effectiveness as a counterterrorism measure had not yet been verified ("Indo-yo kyuyu," 2009). As pledged, the refueling activity was terminated on January 15,2010 , soon after the DPJ took power. While the new ruling party fulfilled its promises, it was also concerned that the end of refueling support might harm Japan's alliance relationship with the US. The inception of the Hatoyama-led DPJ government also caused an imbroglio in the ongoing relocation issue of US Futenma Air Station in 
Okinawa, and Hatoyama's unreliable attitude seriously disappointed the US side ("Futemma-isetsu," 2010). Given these concerns, the GoJ took its support to Haiti, which the US had traditionally regarded as its "backyard," as a prime opportunity to repair relations with the US.

\section{Legal Foundations of Japan's Participation}

\subsection{The Division of Labor Between the JDR and SDF Acts}

In the case of Haiti, as mentioned above, both the civilian and SDF medical contingents were empowered under the JDR Act, while SDF peacekeepers represented by the JEG were deployed under the PKO Act. Generally speaking, the GoJ assumes that the PKO Act deals with cases related to armed conflict, while the JDR Act covers situations after natural and human-induced disasters, such as the collapse of a large-scale building or a crude oil spill (Wada, 1998, pp. 27-30, pp. 37-41). However, neither law anticipates a situation of complex emergency, which posed a considerable challenge to the GoJ regarding how it might combine the JDR and PKO Acts to cope with Haiti's emergency. As a result, both statutes encountered the gaps between their legal assumptions and the reality of the disaster-affected nation.

\subsection{The Deployment of JDR Medical Contingents}

As discussed earlier, the GoJ dispatched both the civilian medical team and the SDF medical unit under the JDR Act. According to national law, the GoJ can potentially dispatch four different types of JDR team: a rescue team, a medical team, an expert team, and an SDF unit (Nakauchi, 2011, pp. 7-8). The medical team is a civilian body mainly comprised of medical professionals who are registered and trained by the JICA. Meanwhile, the SDF unit could assume various roles, such as rescue and the transportation of relief goods, but was also supposed to work unarmed under the JDR Act. In Haiti, the SDF team focused on medical assistance.

Although there was basically no legal limit to the application of the JDR Act for emergency relief to Haiti, two problems arose regarding the deployment of the civilian medical team: the delayed dispatch and the issuance of security provision. First, the civilian medical team did not arrive at the disaster-affected site until January 17, five days after the earthquake. This arrival was relatively late, considering that the time limit for lifesaving 
under a disaster is usually estimated at 72 hours. In comparison, the emergency rescue teams from the US, China, and the European countries arrived within a day or two ("Haichi e kakkoku-enjo-tai," 2010). The reason for this initial delay was twofold. First, the GoJ's decision-making was hamstrung by the fact that the Haitian government, which was still reeling from the severe earthquake, could not promptly make a formal request for emergency relief. Given the security concerns in Haiti, the GoJ opted for a cautious approach by sending an advance survey team before making their decision regarding the deployment of a civilian medical team (Secretariat of JDR Team, 2011). As seen below, the dispatch of an advance survey team before the deployment of the civilian medical team proved useful to facilitate the JDR's works, but it also caused some delay in the deployment of the civilian medical team.

Second, the unexpected reality of the complex emergency raised the practical question of security provisions to protect the civilian team. Needless to say, the civilian medical contingent carries no weapons, but under the JDR Act, as explained earlier, the SDF medical unit was also sent unarmed. This legal stipulation left a problem of how to protect the civilian JDR team under circumstances of complex emergency. Eventually, Sri Lankan peacekeeping forces provided protection to the JDR civilian medical team (Secretariat of JDR Team, 2011). Even though the civilian contingent completed their work without facing any impending security threat, the Haitian experience highlighted the limits of the JDR Act, especially regarding the protection of Japanese nationals when insecurity existed in a disaster-affected area.

\subsection{MINUSTAH Deployment}

In light of this legal basis, the JEG deployment to MINUSTAH was more problematic. As seen already in previous chapters, fulfillment of the Five Principles is a prerequisite before any military contribution to a UNPKO becomes legal. Unfortunately, no cease-fire agreement existed in Haiti because the leader of one of the warring parties, President Aristide, remained in exile. Determined to contribute the JEG to MINUSTAH, the GoJ devised a legal loophole by arguing as follows: the armed groups in Haiti were informally organized and therefore an armed conflict was nonexistent, even if there was some insecurity on site ("Haichi-PKO ni jieitai," 2010). Considering the anarchic situation in Haiti, this political rhetoric was criticized as sophistry, but it nevertheless enabled the GoJ to 
dispatch the JEG as a part of MINUSTAH. The similar logic would also be applied to maintain the military contribution to South Sudan under de facto civil war conditions.

\section{Overview of Japan's Activities}

Japan provided various forms of assistance to Haiti, ranging from military deployment to aid through international organizations and the provision of emergency supplies by NGOs. In this section, we will concentrate in particular on the activities of JDR medical assistance and the deployment of JEG peacekeepers to MINUSTAH.

\subsection{The Activities of the Medical Components Under the JDR Act}

Soon after the earthquake, the GoJ deployed first the civilian medical team and then the SDF medical team under the existing JDR Act. Initially, as seen earlier, the GoJ's response was relatively slow due to a lag in the Haitian government's request for assistance and the need to send a survey team in advance to assess local security conditions. The day after the earthquake (January 14), this advance survey team left for Haiti to prepare the ground for the medical deployment under the JDR Act, since the GoJ had concerns about the volatile local security environment. Afterward, a JICA official, who had served as the head of the civilian medical team, gave a positive assessment of the performance of the advance team in selecting an appropriate venue for their work (Secretariat of JDR Team, 2011, p. 9). At first, the advance survey team examined the possibility of deploying the civilian medical team to the capital city of Port-au-Prince. This idea was quickly abandoned, however, partly because insecurity in the metropolis was too serious and partly because emergency relief teams from other countries had already arrived there. Instead, the decision was made to dispatch the civilian medical team to Léogâne City, approximately $40 \mathrm{~km}$ west of Port-au-Prince. Léogâne had also suffered from serious damage, with an estimated 3000 dead and 10,000 wounded (Secretariat of JDR Team, 2011, p. 8). Moreover, about 90 percent of the city's buildings had collapsed. Nevertheless, Léogâne had several advantages that made it suitable for the deployment of JDR medical teams, such as the city's relative safety, security provision by the nearby Sri Lankan peacekeepers, and the availability of water and electricity (Secretariat of JDR Team, 2011, p. 15). 
In addition, no other countries had yet based their medical assistance there. Although the dispatch of this advance survey team initially delayed the Japanese deployment, their work in Léogâne proved useful in facilitating the efficient start-up of subsequent JDR activities.

On January 16, three days after the earthquake (Japan time), the GoJ chartered a private jet to transport the civilian medical team to Miami. As the ASDF happened to be participating in a joint exercise at the US Homestead Air Reserve Base in Florida, their C-130H transportation aircrafts carried the team from Miami to Port-au-Prince (MoD, 2010a). The JDR Act, amended in 1992, already endorsed such civil-military cooperation for the purpose of disaster relief (see Chap. 3), but this was the first example of such cooperation occurring in practice. After dropping off the medical team, the same ASDF transport plane returned to the US with 34 Haitian earthquake victims on board in order to provide them with immediate medical care. The civilian medical team, comprising 26 members, began to provide assistance in a nursing school in Léogâne on January 18. They were the first medical team to arrive in Léogâne and treated 534 people in total in the first eight days (JICA, n.d.). After this period, medical assistance was taken over by the SDF medical unit, which was made up of approximately 100 personnel. The SDF medical team inherited the medical material and tents from the civilian team (Urakami \& Saito, 2016, p. 173). Over a roughly three-week period, starting on January 23 , the SDF medical unit treated 2954 people in total (Joint Staff Office, 2010). Upon completion of the SDF medical unit's activities on February 13, medical care assistance was entrusted to the JRCS's medical team, which took over the following day. Both the civilian and military JDR medical contingents focused on providing emergency medical support, such as the treatment of external injuries, while JRCS personnel mainly took care of patients with chronic diseases. This initiative not only promoted collaboration between the civilian and military medical teams under the JDR framework, but also enhanced the practical implementation of collaboration between the governmental and nongovernmental assistance teams. The fortified cooperation with the nongovernmental humanitarian organization in Léogâne expanded the scope of the "All Japan" approach, which had originally concentrated on the field of infrastructure development and restoration. 


\subsection{The Military Dispatch to MINUSTAH Under the PKO Act}

Following the deployment of medical assistance teams under the JDR Act, the GoJ contributed the JEG to MINUSTAH with unprecedented speed. The minimal political controversy surrounding deployment for purposes of emergency relief also facilitated the quick deployment of JDR personnel.

Upon the adoption of the aforementioned UNSCR 1908 on January 19, the UN requested on the same day that the GoJ dispatch the SDF to MINUSTAH with the following contributions: an infantry unit for security, an engineering corps to remove debris and repair roads, and a largesize transportation helicopter $(\mathrm{MoD}, 2010 \mathrm{~b}, \mathrm{p} .4)$. In response to this request, on January 25 , the GoJ expressed its will to dispatch the JEG. Two days later, an SDF survey team flew to the disaster site, followed by the February 5 adoption of the "Haiti IPC Operations Implementation Plan," which determined the details of the SDF deployment to MINUSTAH (Cabinet Office, 2010).

To support post-disaster reconstruction, the JEG again constituted the largest part of the Japanese delegation (Cabinet Office, 2010, pp. 3-5). Among the 350 members who comprised the JEG contingent, approximately 190 were directly placed under the MINUSTAH mission, while the other 160 were deployed outside of the UN framework as support personnel tasked with assisting the JEG personnel within MINUSTAH (Uesugi, 2018, pp. 199-200). These separated JEG personnel had various tasks, and particularly important among them was coordination with civilian organizations, such as the Japanese embassy and the JICA in Haiti. The combined deployment of UN personnel and the support personnel initially emerged in the GSDF deployment to Iraq and developed as one of the main engines to facilitate civil-military cooperation.

Alongside the large-scale engineering force, two staff officers and five liaison officers were also deployed to MINUSTAH Headquarters to facilitate smooth communication between the JEG side and the UN side (see Chaps. 3, 5, and 6). Albeit outside the formal deployment to the MINUSTAH, the MSDF and ASDF transportation forces also operated to support the JEG peacekeepers.

Under emergency conditions after the earthquake, the decision was made to deploy the JEG at the earliest possible opportunity. In consequence, the first set of SDF peacekeepers arrived on site on February 8, only four weeks after the earthquake. This was an extraordinarily rapid deployment, since it usually takes several months, at least, to dispatch an 
engineering corps with the capacity to deliver heavy equipment to the site. This time, the GoJ swiftly chartered a Ukrainian "Antonov," the largest transport plane in the world, and transported heavy machines by air. Its first flight transported four pieces of heavy equipment, such as shovelloaders, and arrived on February 11, 2010 (Juki ga haichi tochaku, 2010).

In total, the JEG delivered 150 vehicles, including 40 pieces of heavy equipment (e.g., bulldozers and hydraulic excavators), to the field. Because the deployment was based on UNSCR 1908, the JEG focused above all on their restoration and reconstruction duty, which had been newly tasked to MINUSTAH. Once deployed, the JEG mainly operated in and around Port-au-Prince, which had been most seriously hit by the earthquake, while MINUSTAH originally focused more on the "robust" mandate. In Haiti, Japanese engineers carried out more than 200 tasks, such as the removal of a huge amount of rubble and the construction and repair of camps for internally displaced people (IDPs) (Cabinet Office, 2013a). They also repaired roads leading to the border with the Dominican Republic (Cabinet Office, 2013b).

\subsection{The Development of the "All Japan" Approach}

In addition to the official support to MINUSTAH, the JEG also provided direct assistance to the local population through close collaboration with Japan's ODA, or the "All Japan” approach (see Chaps. 3 and 6). Having learned from previous experience, the "All Japan" approach in Haiti was carried out in a more elaborate manner. By deploying its staff officers to MINUSTAH Headquarters, the Japanese side could incorporate expanded "All Japan"-related works into the UN enterprise. With MINUSTAH approval, the JEG carried out construction works intended for use by local residents. When the JEG rebuilt the Sigueneau tuberculosis sanatorium as a part of MINUSTAH duties, for example, the Japanese embassy contributed ODA funds, using grant aid called the Cultural Grant Assistance (MoFA, 2018), to build a well and to donate an X-ray machine. Engineering work under the MINUSTAH framework and funding from Japan's ODA were also combined to restore an orphanage in Malpasse.

The "All Japan" approach also enhanced collaboration between the JEG's tasks and parallel NGO works also funded by Japan's ODA. In the reconstruction of a school for blind children, for instance, the JEG first dismantled the damaged building and removed debris, before a Japanese NGO, namely Japan Association for Aid and Relief (AAR), constructed a 
new building. To connect the JEG, deployed as UN peacekeepers, with the NGO works, AAR first made a request to the MINUSTAH Headquarters for help; then, the UN side tasked the JEG to work as AAR had requested.

Peace Winds Japan (PWJ), another Japanese NGO that had begun to assist Haiti immediately after the earthquake, also established close cooperation with the JEG. PWJ provided the local population with emergency goods, such as tents and rubble removers, and encouraged the residents to clean up their neighborhood, but the playground used for rubble collection soon grew full. PWJ considered arranging the removal of this rubble by a private company, but the NGO soon found that the JEG could clear the site free of charge. As in the case above, PWJ asked MINUSTAH Headquarters to assign this task to the JEG (Urakami \& Saito, 2016, p. 175).

To foster closer relations with the local community, the JEG further expanded the range of civil affairs support, such as the provision of medical and hygiene education and the exhibition of Japanese culture, including sumo wrestling, karate, and calligraphy. Japanese peacekeepers operated in Haiti for nearly three years and withdrew at the end of 2012. At the request of the Haitian government, before their final departure, the GoJ donated their second-hand heavy equipment (e.g., bulldozers), as well as their used modular accommodation buildings, to the local community.

\section{Outcomes of Japan's EFForts and Related Challenges}

\subsection{A Collaborative Structure to Enable "Seamless" Assistance}

From the end of the 1990s onward, the GoJ emphasized the importance of "seamless" support to fragile states (see Chap. 3). We can say that the deployment to Haiti served as a meaningful test case to develop such "seamless" assistance by fostering civil-military partnerships in practice. This was possible in Haiti partly because civil-military cooperation was smoothly formed through the emergency medical assistance just after the 2010 earthquake, and partly because the SDF peacekeepers were tasked with a restoration and reconstruction mandate that displayed high affinity with the work of their civilian counterparts. 
In Haiti, civil-military collaboration was remarkable in that it developed in two distinct modes, that is, a "subsequent collaboration" and a "simultaneous collaboration" mode. First, the subsequent partnership mode is a partnership where a civilian organization, newly arriving on site, takes over assistance from a military organization that has been operating so far, or vice versa, and continues with the existing activities in succession. This mode was developed in the initial phase of emergency medical support, when the JDR civilian team handed over control of medical provision to the SDF medical unit, which was succeeded in turn by the JRCS team when the SDF was withdrawn. Upon completing the early medical assistance phase, the SDF peacekeepers still carried on with Japan's support to Haiti, although a change in venue from Léogâne to Port-au-Prince prevented them from handing over directly from disaster relief to peacekeeping.

Second, the simultaneous collaboration mode is defined as a partnership where a civilian organization works in parallel with a military organization. This approach also emerged to consolidate the "All Japan" approach between the JEG peacekeepers and the ODA. In Haiti, governmental and nongovernmental partnerships were also strengthened, as seen in the cases of SDF cooperation with the JRCS and Japanese NGOs. In the meantime, "seamless" assistance in Haiti was also promoted by the unintended coincidence of the availability of ASDF transportation aircraft in Florida, which was the first case of such civil-military cooperation under the JDR Act. This collaboration happened to work well on this occasion, but it also highlighted the necessity of prior preparation ahead of such a joint operation.

Despite the challenging circumstances of a complex crisis, Haiti consequently became a successful case with previously unseen efforts enhancing civil-military cooperation. If similar collaboration is to be implemented in the future, then the SDF's mandate under the JDR Act needs to be expanded to include the work of rubble removal and damaged building dismantlement, reconstruction of roads and damaged facilities, and construction of new facilities.

\subsection{The Gap Between Existing Legal Structures}

The Haitian experience demonstrated the limits of the existing legal structure in responding to complex crises, since neither the JDR Act nor the PKO Act anticipated such a complicated situation. In particular, since the JDR Act did not expect to deploy personnel to a conflict-affected country, 
the dispatch of the civilian team to Haiti raised questions regarding how to protect civilian personnel when a disaster occurs in a war-torn location. Indeed, there have been other cases of conflict-prone countries struck by natural disaster, such as Indonesia and Sri Lanka, which were both hit by an earthquake off Sumatra in 2004 (Uesugi, 2018, pp. 204-205). Likewise, security situations could be worsened while disaster relief aid is being provided, as a JDR civilian medical team once experienced in the Philippines in 2013 when the great typhoon Haiyan (also known as Yolanda) hit the Southeast Asian nation (Yoshitomi, 2018, p. 208). In the case of Haiti, as mentioned earlier, Sri Lankan peacekeepers provided security to the Japanese civilian teams, but such protection might not always be available. When deployed under the JDR Act, meanwhile, the SDF are supposed to work unarmed and are thus unable to provide protection to their Japanese civilian counterparts.

A similar problem regarding the protection of civilian personnel could happen not only to the civilian JDR members, but also to the civilian staff of NGOs. Throughout JDR medical assistance, for example, the SDF medical unit was sharing its base with an international NGO, called "World Wide Village" (MoD, 2010c, p. 5). Even if the NGO came under attack, unarmed SDF personnel deployed as a JDR team would have no means of protecting the civilian staff (Uesugi, 2018, pp. 204-205). This proved another limit of SDF deployment under the JDR Act, especially when plunged into the situation of a complex emergency, as in the case of Haiti (Uesugi, 2018, p. 204).

Fortunately, no serious security-related incidents occurred during the deployment of Japanese personnel in Haiti, but the experience highlighted the necessity of considering the issue of security provision during this deployment under the JDR Act. In addition, the need to expand the SDF's role in JDR-related activities was also highlighted. Considering these elements, it is necessary to investigate how the SDF's roles can be more actively utilized in order to enhance Japanese capacity in disaster relief.

\section{Summary OF Chap. 7}

The case of Haiti was a unique experience for Japanese peacekeepers operating in conditions of complex crisis, in which the problems of a natural disaster and an armed conflict overlapped. This led to the first case of Japan invoking the JDR Act to deploy both a civilian JDR team and the 
SDF medical unit, while also authorizing a military deployment to a UN mission under the PKO Act. The peculiarity of the legal situation formed several distinct features in Japan's support to the earthquake-hit country. First, following the initial JDR works, the SDF peacekeepers were sent to Haiti very promptly, with few objections to the military contribution to MINUSTAH, even though it seemed questionable whether the ground situation fulfilled the Five Principles. This proved that a disaster-related case could more easily garner political and public support for SDF deployment to a UNPKO. Second, the complex crisis promoted new forms of civil-military cooperation, as well as governmental and nongovernmental collaboration. In particular, the "All Japan" approach was implemented smoothly in Haiti, drawing from the previous experiences in East Timor, Iraq, and elsewhere. This achievement exactly corresponded with the larger international trend of "integration" in UNPKOs.

As for "robustness," despite acute instability in Haiti, the SDF did not encounter severe security threats and no serious problems regarding "robustness" emerged during the deployment to MINUSTAH. In the meantime, the protection of civilian personnel in a complex crisis appeared as an important agenda item for the future, since neither the JDR Act nor the PKO Act was designed to cope with such situations.

\section{Note}

1. In 2011, the year after the Haitian earthquake, Japan was also hit by another great earthquake in the northeast region, accompanied by a huge tsunami and the breakdown of a nuclear power plant in Fukushima. The disastrous experience of Great East Japan Earthquake further strengthened Japan's disaster consciousness, both at the government level and in society.

\section{REFERENCES (IN ENGLISH)}

Clinton, B. (2010). Our commitment to Haiti. Innovations: Technology, Governance, Globalization, 5(4), 3-5. https://doi.org/10.1162/INOV_ a_00037

MoFA. (2018, April 13). Official development assistance (ODA): Cultural grant assistance. https://www.mofa.go.jp/policy/oda/category/cultural/index.html

United Nations. (2004, February 29). Security Council authorizes three-month multinational interim force for Haiti. UN News. https://news.un.org/en/ story $/ 2004 / 02 / 95652$-security-council-authorizes-three-monthmultinational-interim-force-haiti 


\section{REFERENCES (In JAPANESE)}

Cabinet Office. (2009, January). Jiei-tai-boei-mondai ni kansuru yoron-chosa [Opinion poll on the self-defense forces and defense affairs]. https://survey. gov-online.go.jp/h20/h20-bouei/index.html

Cabinet Office. (2010, February 5). Haichi-kokusai-heiwa-kyoryoku-gyomu jisshi-keikaku [Japan's international peace cooperation in Haiti: Implementation plan]. http://www.pko.go.jp/pko_j/data/pdf/02/data02_24.pdf

Cabinet Office. (2013a, February). Haichi-kokusai-heiwa-kyoryoku-gyomu (2010 (heisei-22) nen-2013 (heisei-25) nen) [Overview of international peace cooperation activities in Haiti, 2010-2013]. Secretariat of the International Peace Cooperation Headquarters. Retrieved April 17, 2021, from http://www.pko. go.jp/pko_j/result/haiti/haiti02.html

Cabinet Office. (2013b, May). Haichi-kokusai-heiwa-kyoryoku-gyomu no jisshi no kekka [Japan's international peace cooperation in Haiti: Outcomes]. http:// www.pko.go.jp/pko_j/data/pdf/04/data04_24.pdf

Futemma-isetsu: "Nichi-bei-goi-riko o hikan," bei-moto-kokumu-fuku-chokan ga hatsugen [Former US Deputy Secretary of State is pessimistic about the implementation of the US-Japan agreement on the relocation of the Futenma air station]. (2010, January 17). Yomiuri Shimbun, p. 2.

Haichi e kakkoku-enjo-tai: 4-man-nin taizai no bei mo honkaku-ka: Dai-jishin [International society dispaching rescue teams Haiti hit by the great earthquake: The US provides a full-fledged assistance, with 40,000 US citizens stayinig in Haiti]. (2010, January 14). Asabi Shimbun (evening ed.), p. 12.

Haichi-PKO ni jiei-tai haken e: Fukko-shien ni 300-nin [300 man SDF unit to be deployed to the PKO in Haiti to support reconstruction]. (2010, January 25). Asahi Shimbun (digital). http://www.asahi.com/special/haiti/ TKY201001250316.html

Indo-yo kyuyu, minshu Hatoyama-daihyo "kihonteki-ni encho-shinai" [Democratic Party's head Hatoyama remarks that the party will not extend Japan's logistics support operation in the Indian Ocean]. (2009, July 29). Asabi Shimbun (online). https://www.asahi.com/senkyo2009/news/ TKY200907290349.html

JICA. (n.d.). 2010-nen-haichi-jishin:Zeijaku-kokka ni okeru kyuen-katsudo to kokusai-kyocho no juyo-sei [2010 Haiti earthquake: The importance of disaster relief and international cooperation in a fragile state]. Retrieved April 8, 2021, from https://www.jica.go.jp/jdr/activities/case_jdr/2010_01.html

Joint Staff Office. (2010, February 15). Haichi-kyowa-koku ni okeru kokusaikinkyu-iryo-enjo-tai tou no katsudo-jisseki ni tsuite (1-gatsu 23-nichi-2-gatsu 13-nichi) [Implementation of international rapid medical response activities in Haiti]. https://www.mod.go.jp/js/Press/press2010/press_pdf/p2010 0215.pdf 
Juki ga haichi tochaku, jiei-tai-PKO honkaku-shido e [The SDF's heavy machineries arrives in Haiti: The SFF begins its use in disaster relief operations]. (2010, February 12). Nippon Television News 24. https://www.news24.jp/articles/2010/02/12/10153416.html

MoD. (2010a, January 29). Haichi ni okeru dai-jishin ni taisuru jiei-tai no kinkyu-enjo-katsudo ni tsuite [Regarding the SDF's disaster relief activities in Haiti after the 2010 earthquake]. https://www.mod.go.jp/j/approach/kokusai_heiwa/kokusai_enjyo/2010/pdf/201001_hti_a.pdf

MoD. (2010b, February 9). Haichi ni okeru jiei-tai-butai no PKO-katsudo ni tsuite [Regarding PKO activities of the SDF in Haiti]. https://www.mod.go. jp/j/approach/kokusai_heiwa/pko/pdf/201002_hit/20100209.pdf

MoD. (2010c, April). Jiei-tai no kaigai-katsudo ni okeru bummin-bumon tono kyoryoku [SDF's cooperation with the civilian sector in its overseas operations]. https://www.kantei.go.jp/jp/singi/shin-ampobouei2010/siryou/ hosoku_bunmin.pdf

Nakauchi, Y. (2011). Kokusai-kinkyu-enjo-tai no enkaku to konnichi no kadai: Motomerareru dai-kibo-saigai ni taisuru kokusaikyoryoku no suishin [The development of Japan's disaster response team and its remaining challenges today: Promoting international cooperation toward large-scale natural disasters]. Research Report on the Constitution, 323, 3-12. https:// www.sangiin.go.jp/japanese/annai/chousa/rippou_chousa/backnumber/ $2011 \mathrm{pdf} / 20111201003 . \mathrm{pdf}$

Secretariat of JDR Team. (2011, May). Haichi-kyowa-koku ni okeru jishin ni taisuru kokusai-kinkyu-enjo-tai iryo-chimu katsudohokoku-sho [Report on the activities of the JDR medical team in Haiti after the earthquake]. JICA. https:// openjicareport.jica.go.jp/pdf/12047338.pdf

Uesugi, Y. (2018). Haichi: Jishin-saigai-kyuen kara kokuren-PKO eno tsunagi-me no nai shien [Haiti: Promoting seamless international cooperation from postearthquake disaster relief to the UNPKO in Haiti]. In Y. Uesugi \& H. Fujishige (Eds.), Kokusai-heiwa-kyoryoku-nyumon: Kokusai-shakai eno koken to nihon no kadai [Introduction to international peace cooperation: Japan's contributions to the international community and its policy challenges] (pp. 190-206). Minerva Shobo.

Urakami, N., \& Saito, M. (2016). Haichi [Haiti]. In Y. Uesugi, H. Fujishige, T. Yoshizaki, \& T. Honda (Eds.), Sekai ni muketa oru-japan: Heiwa-kochiku, jindo-shien, saigai-kyuen no atarashii katachi [The "All Japan" approach toward the world: New forms of peacebuilding, humanitarian assistance and disaster relief] (pp. 172-183). Naigai Publisher. 
Wada, A. (1998). Kokusai-kinkyu-enjo saizen-sen: Kuni-doshi no tasukeai-saigaikyuen-enjo-kyoryoku [Frontiers of international emergency aid: International cooperation on emergency relief assistance]. Cooperation Press.

Yoshitomi, N. (2018). Fuiripin ni okeru kokusai-kinkyu-enjo-katsudo [International disaster relief activities in the Philippines]. In Y. Uesugi, \& H. Fujishige (Eds.), Kokusai-heiwa-kyoryoku-nyumon: Kokusai-shakai eno koken to nibon no kadai [Introduction to international peace cooperation: Japan's contributions to the international community and its policy challenges] (pp. 207-208). Minerva Shobo.

Open Access This chapter is licensed under the terms of the Creative Commons Attribution 4.0 International License (http://creativecommons.org/licenses/ by $/ 4.0 /$ ), which permits use, sharing, adaptation, distribution and reproduction in any medium or format, as long as you give appropriate credit to the original author(s) and the source, provide a link to the Creative Commons licence and indicate if changes were made.

The images or other third party material in this chapter are included in the chapter's Creative Commons license, unless indicated otherwise in a credit line to the material. If material is not included in the chapter's Creative Commons licence and your intended use is not permitted by statutory regulation or exceeds the permitted use, you will need to obtain permission directly from the copyright holder.

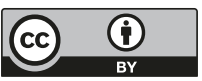

